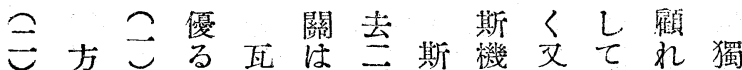
米乙斯熱五く關穖よば逸 榙に瓦之機消年しの關り彼に 諳水つ斯。数關費間て設の汽のて

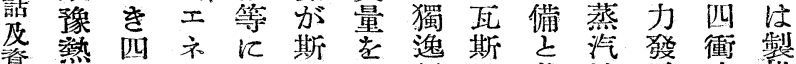

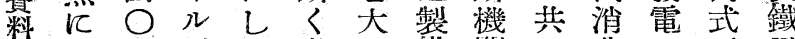
よ正ギて發單鐵關に費は瓦用 るに $、$ 經展位工は蒸率減斯發 製廢達よ濟し設場最汽は少機電 鐵 桼すり的つ備の近名到し關D

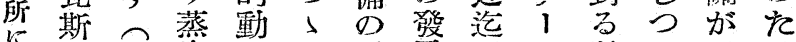

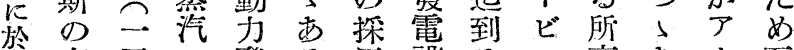
け有平工發る用設るン高西桼

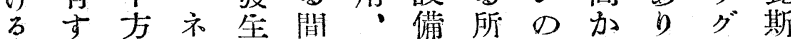

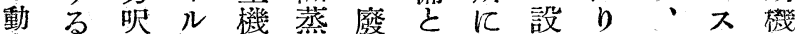

力餘に向關汽熱し淮借き當ブ關

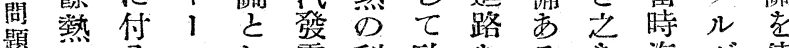

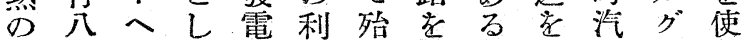
回

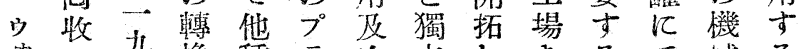

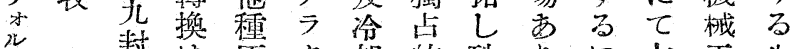

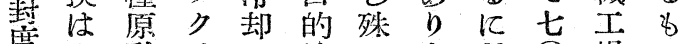
度大動千に地に之攀 ○場の 保 三汽裨

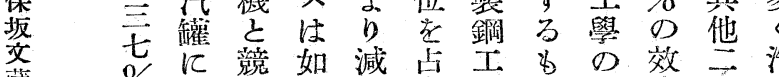

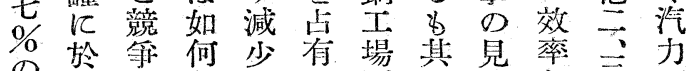

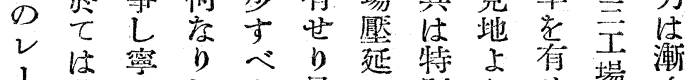

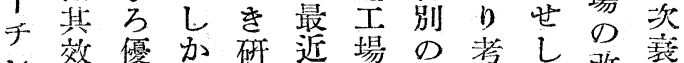

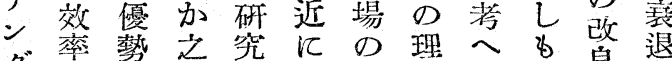

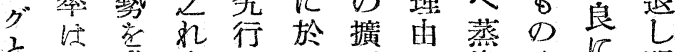

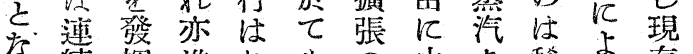

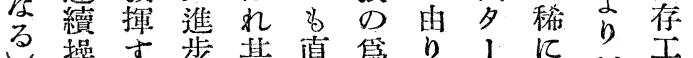
業る步其直点しじし製境 儿跡果焚動疗ンて鐵の

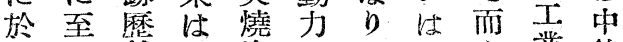
穴然可汽の酉的業後 八り年成罐需斯錯に者 五るのは要機綜磼の

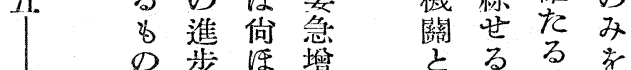
八 あ步症增比導地使 七 現世示少場俥管步捅

监
九 学在り合店濩方

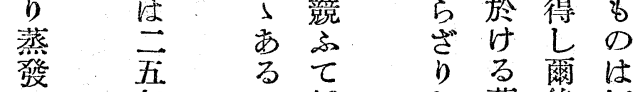
㥒年蒸後極 傅前對用疗汽急め 熱りり り 消速て 面設氐方若耗㢳稀

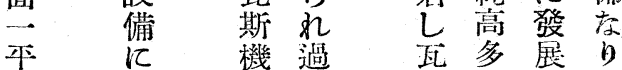

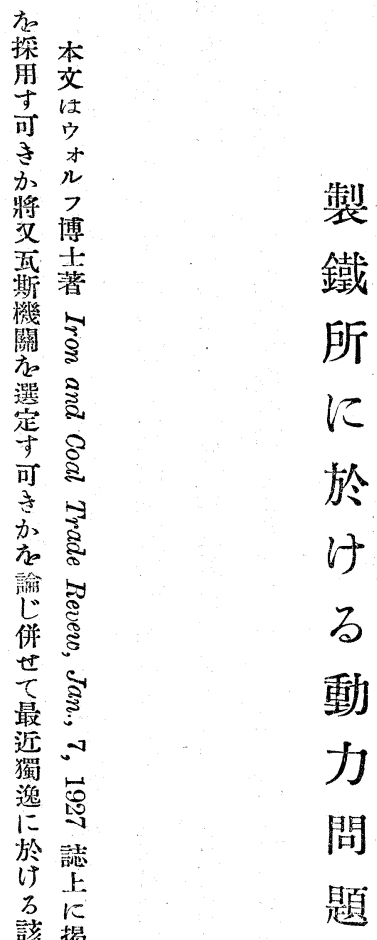

\section{保 ウ}

編

轡於 坂 文 藏 暲 フ 
月六年二，和 㗁

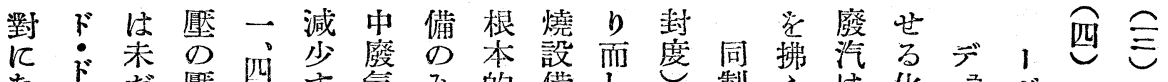

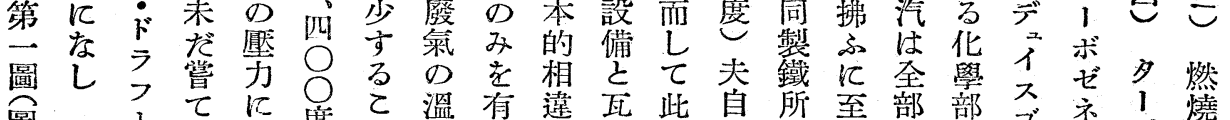

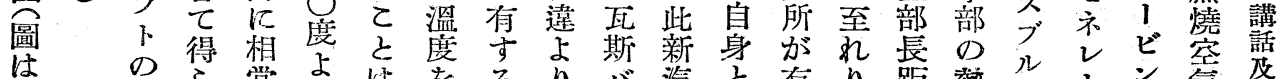

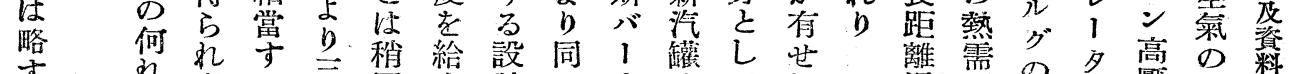

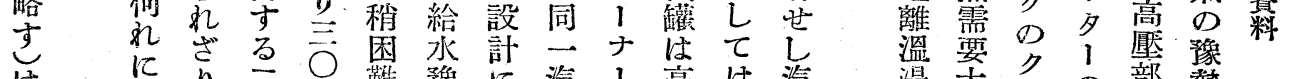

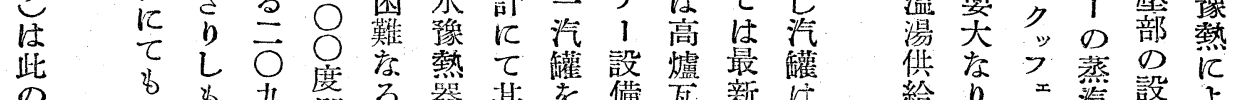

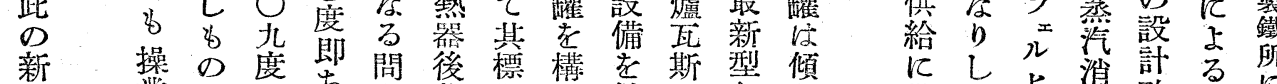

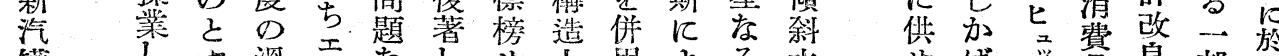

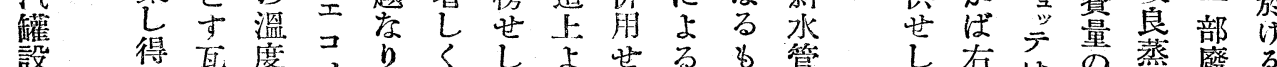

設得瓦度, b

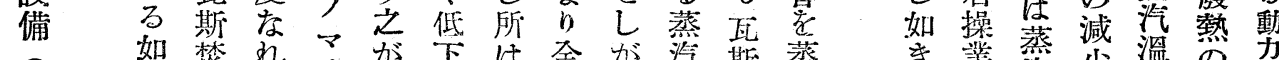

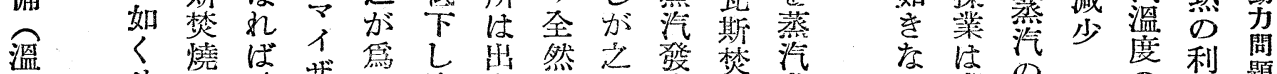

沓紊法確

積斯就に大製損大利經㺟部

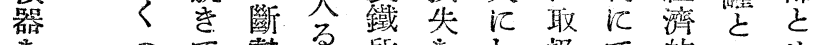

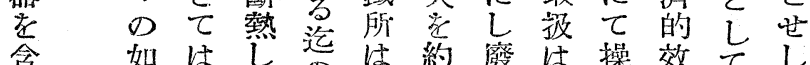

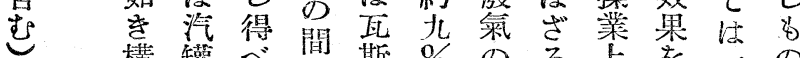

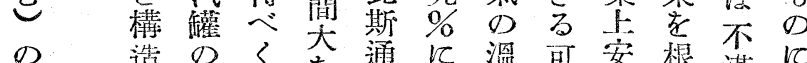

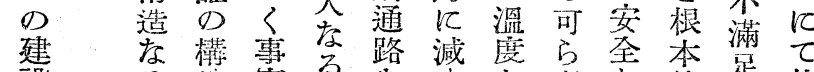

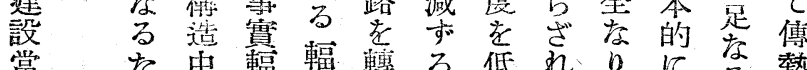

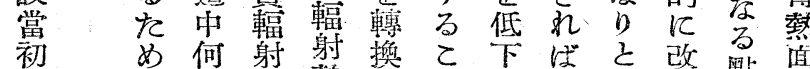

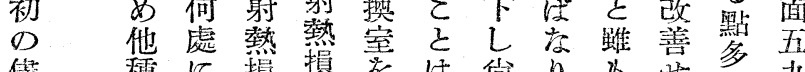

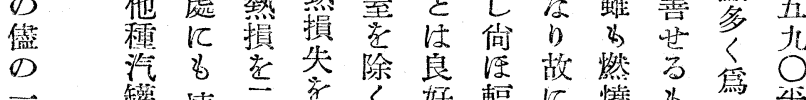

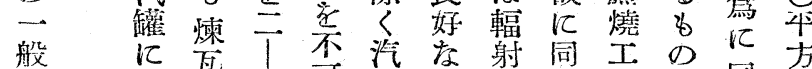

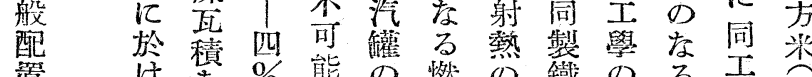

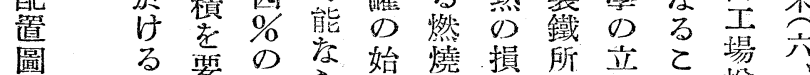

な 如世極ら管笑に場之增三

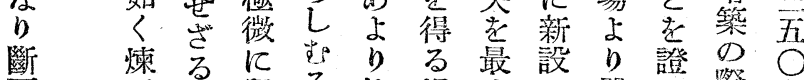

面桼如留る終場省せ嚴然際出

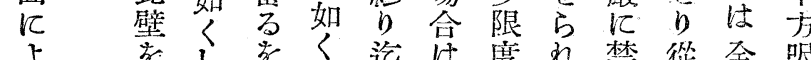

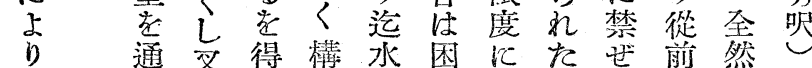

明焉自筑容難留るざす趣常

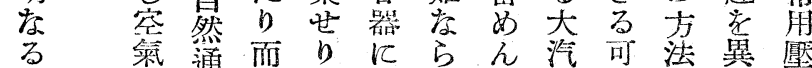

がの風し汽てざと整らはた力

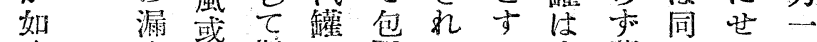

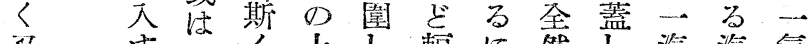

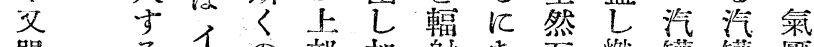

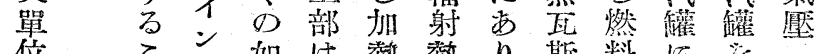

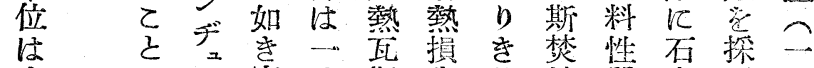

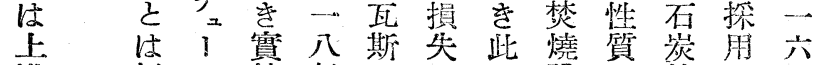

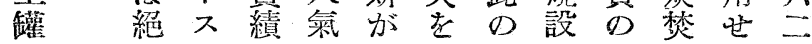

乙 經

同的

工沶源

場る る

は斯齐る

万方扠

合染老其

$\bar{\sigma}$ 蒸固經

公汽守濟

它機 世 的

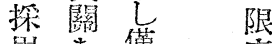

用を嚾度

せ琵少济

る斯索言

果關製氣

自鐡壓

然

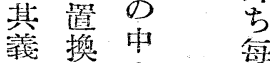

務专の 尔

子 万品方

乙必製时

要鐵五

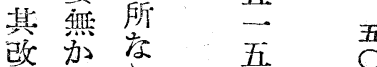

善 b b 教 O

蓕き同度

達例所：度

に最占包

大送場江

風に占

乼機溥 る 


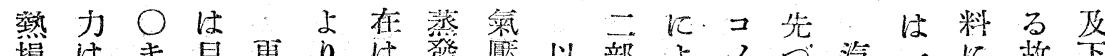

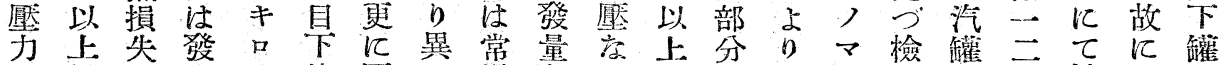

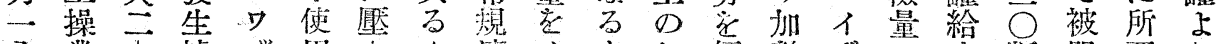

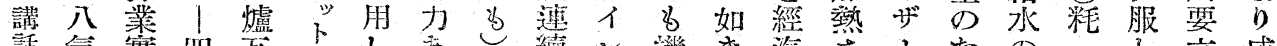

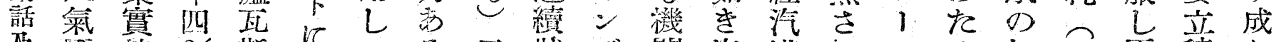

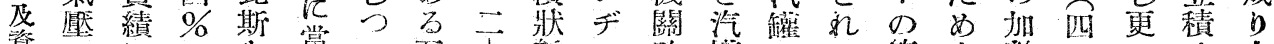

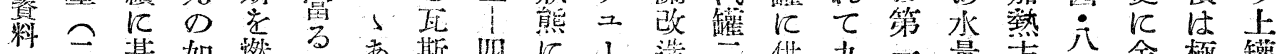

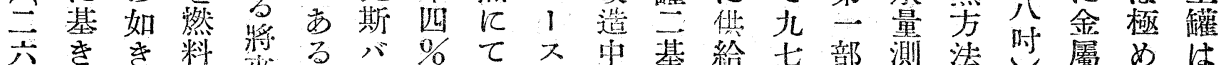

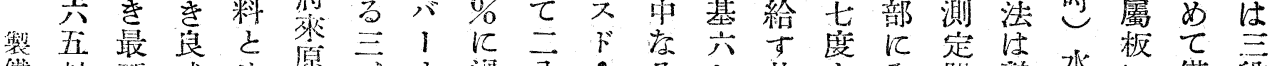

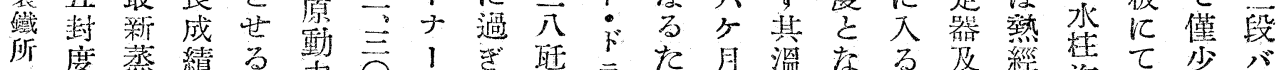

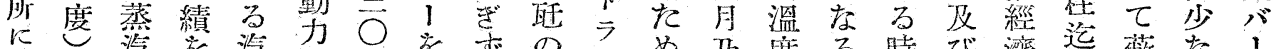

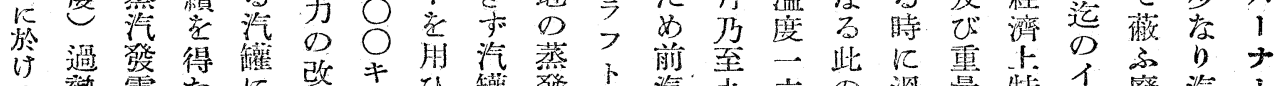

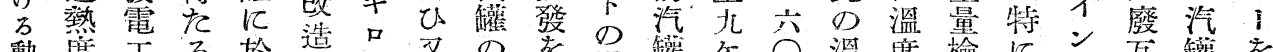

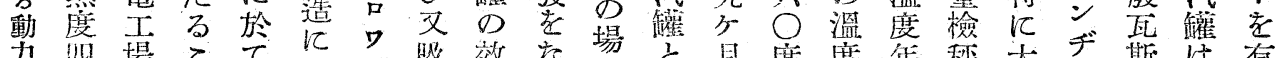

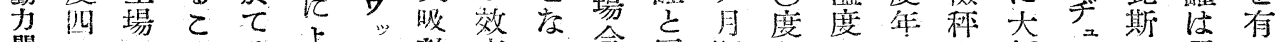

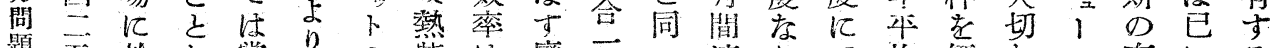

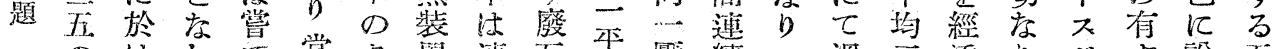

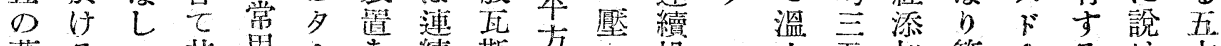

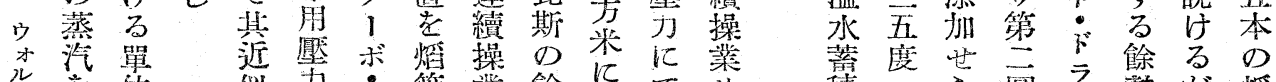

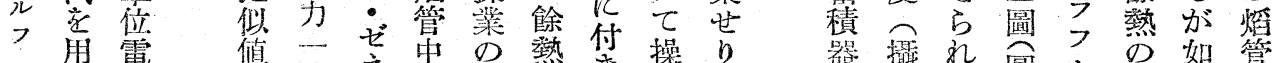

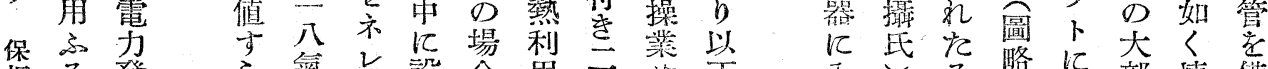

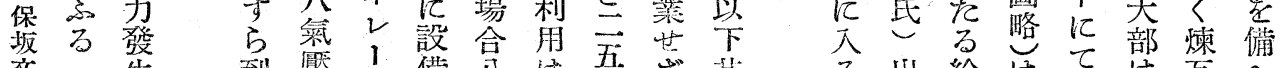

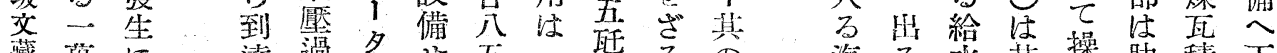

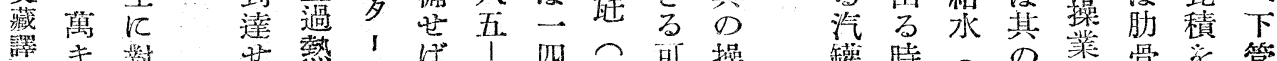

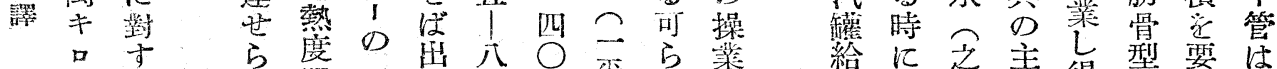

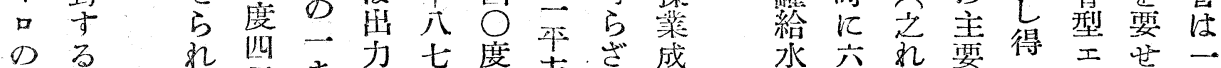

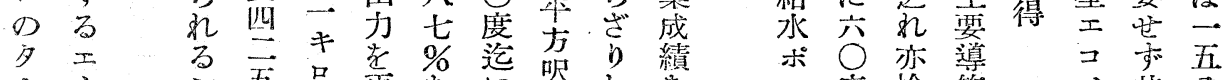

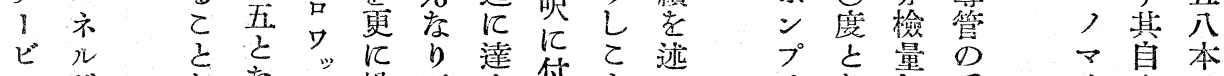

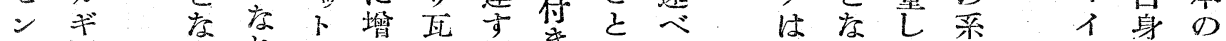
の1くれ時大斯輻吾なん此る且統げ瀰焰

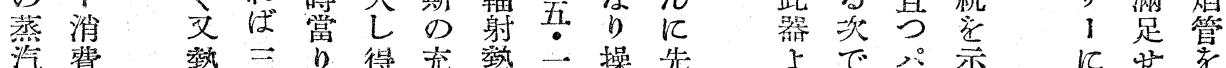

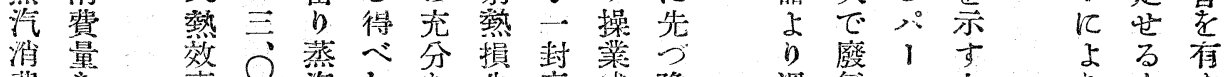

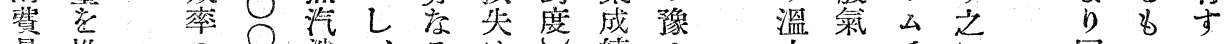

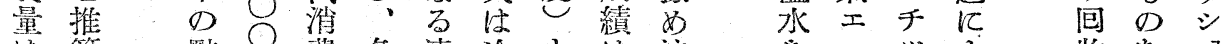

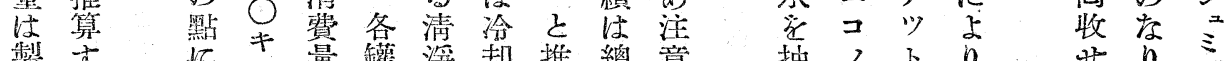

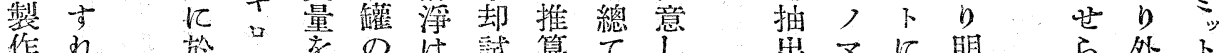

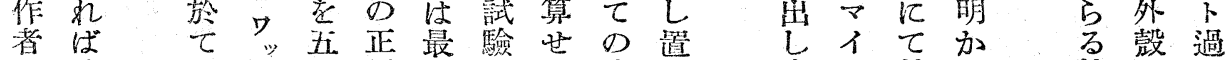

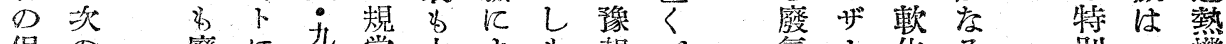

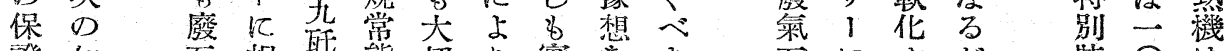

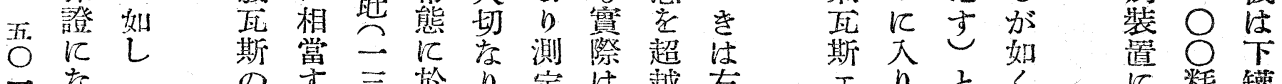

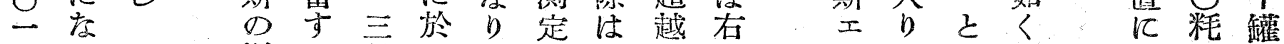

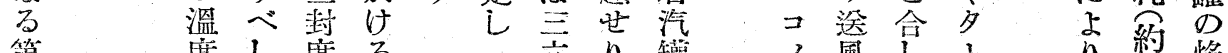

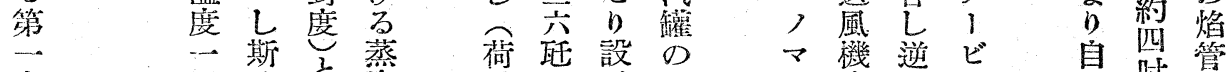

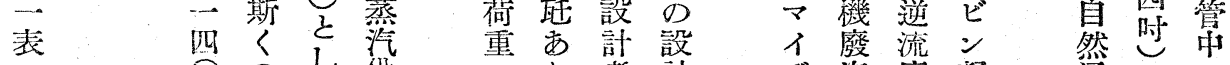

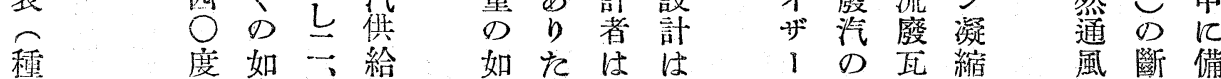

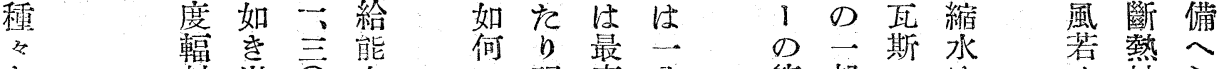
な 射 出 $\mathrm{O}$ 力 几現高八、第部エは 


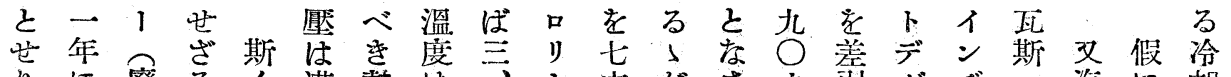

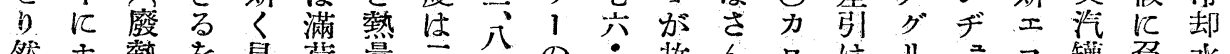

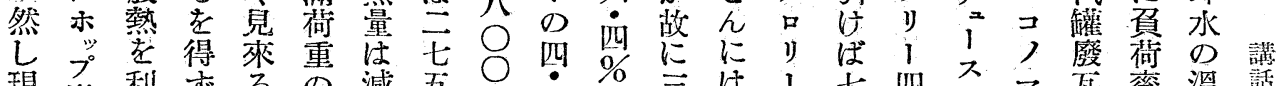
現 呚利吉る

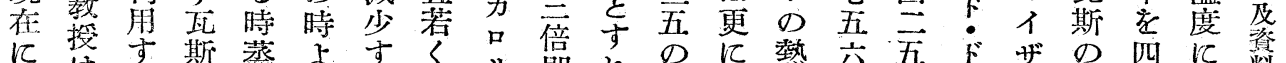

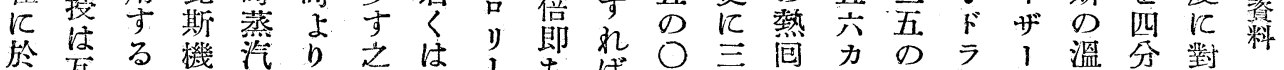

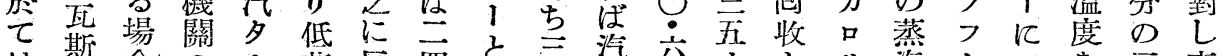
は斯合電熱

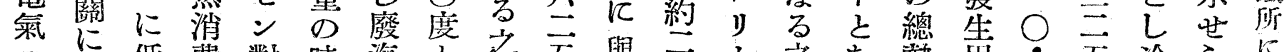

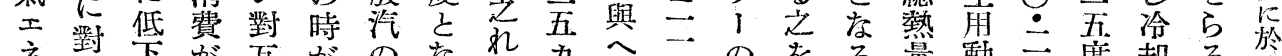

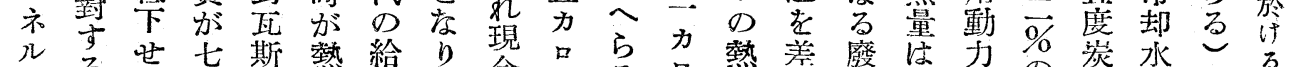

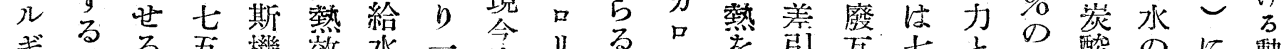
ギる る 五機 效 水

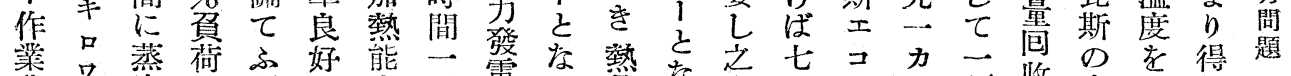

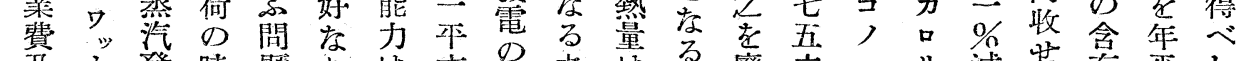

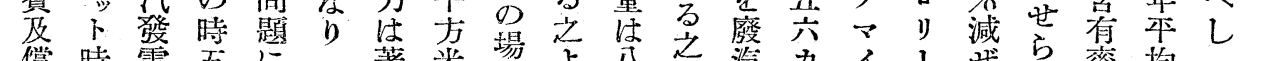

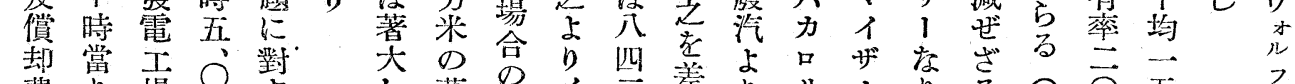

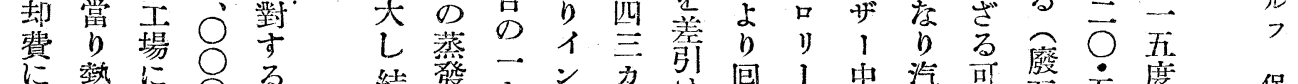

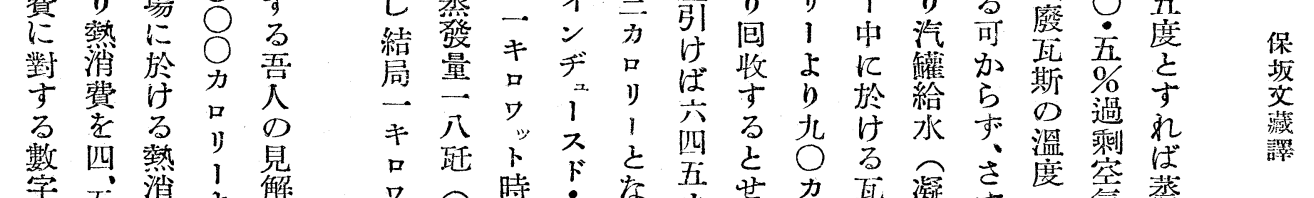

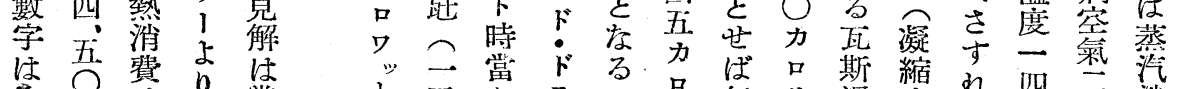

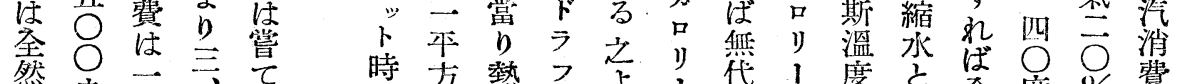

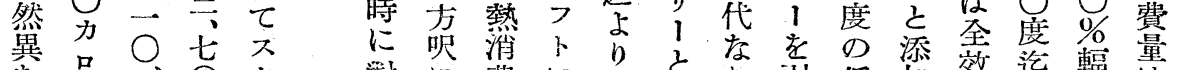

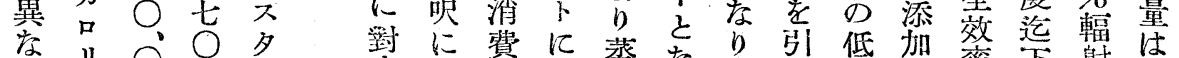

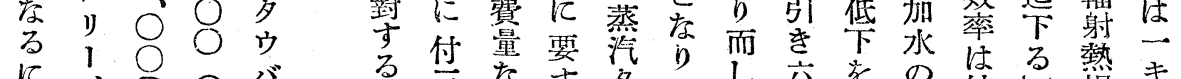

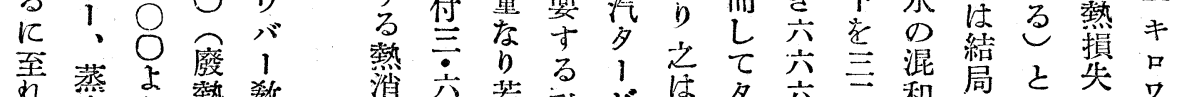

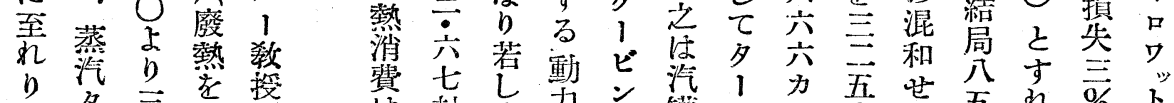

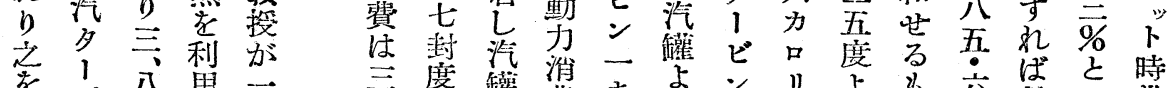
集ビ 八角

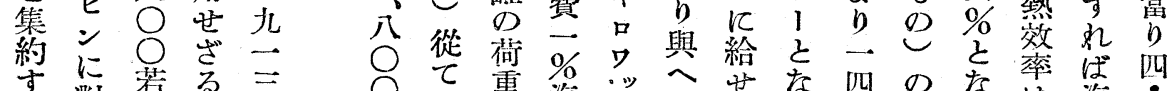

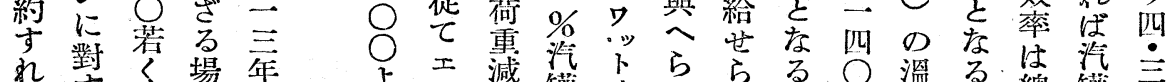

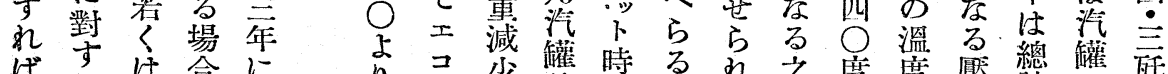

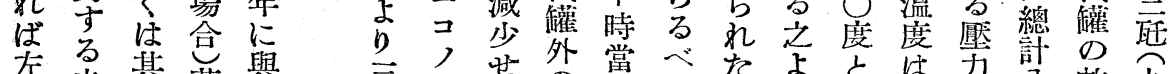

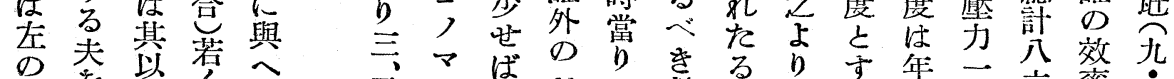

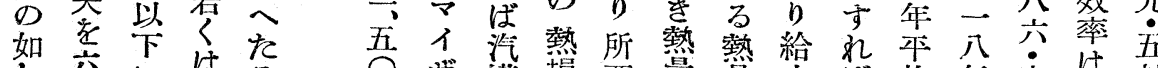
乚六下江る

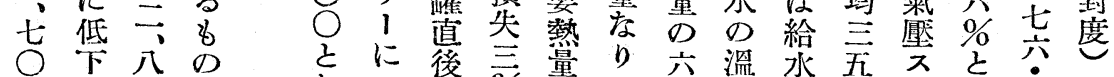

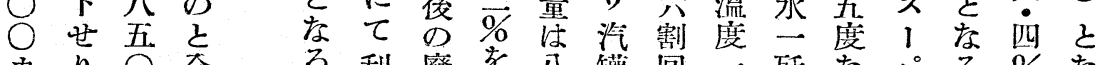

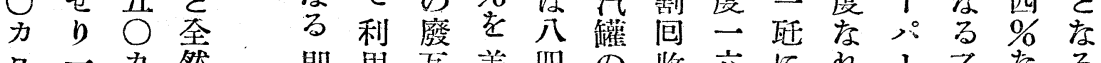

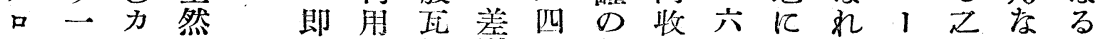
リ九買 ちし斯引司效せ○對ばとなる 1 一 


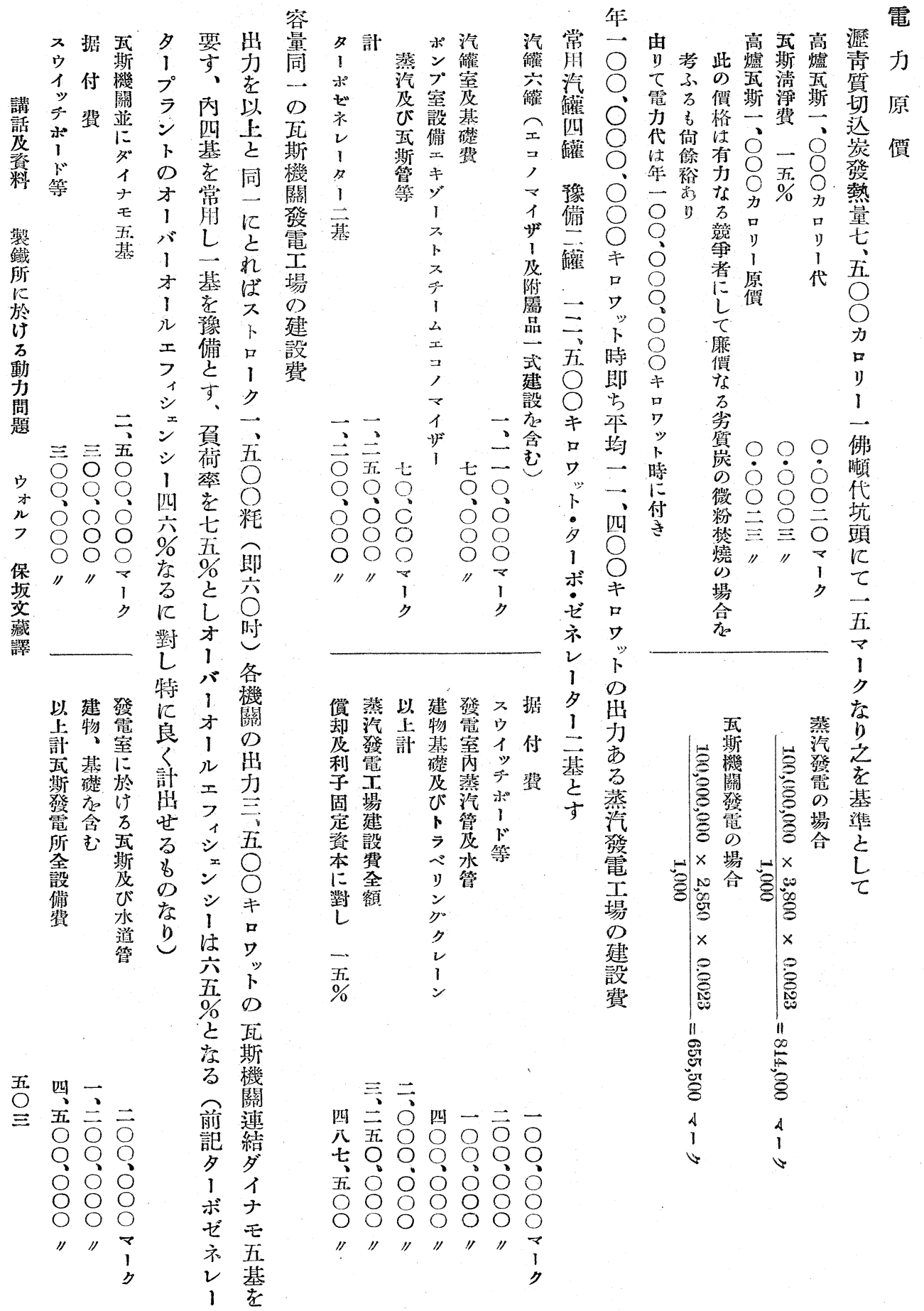




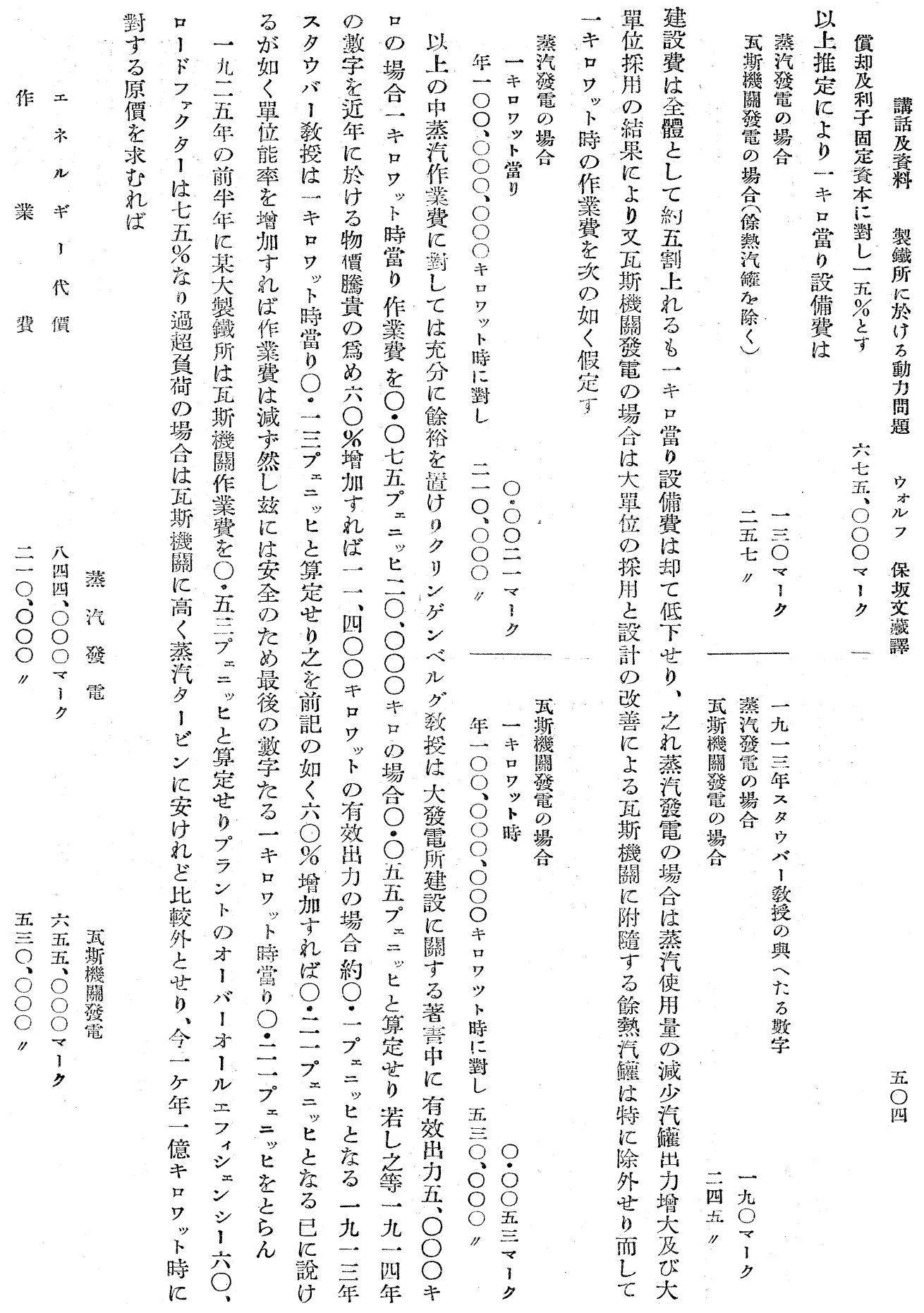




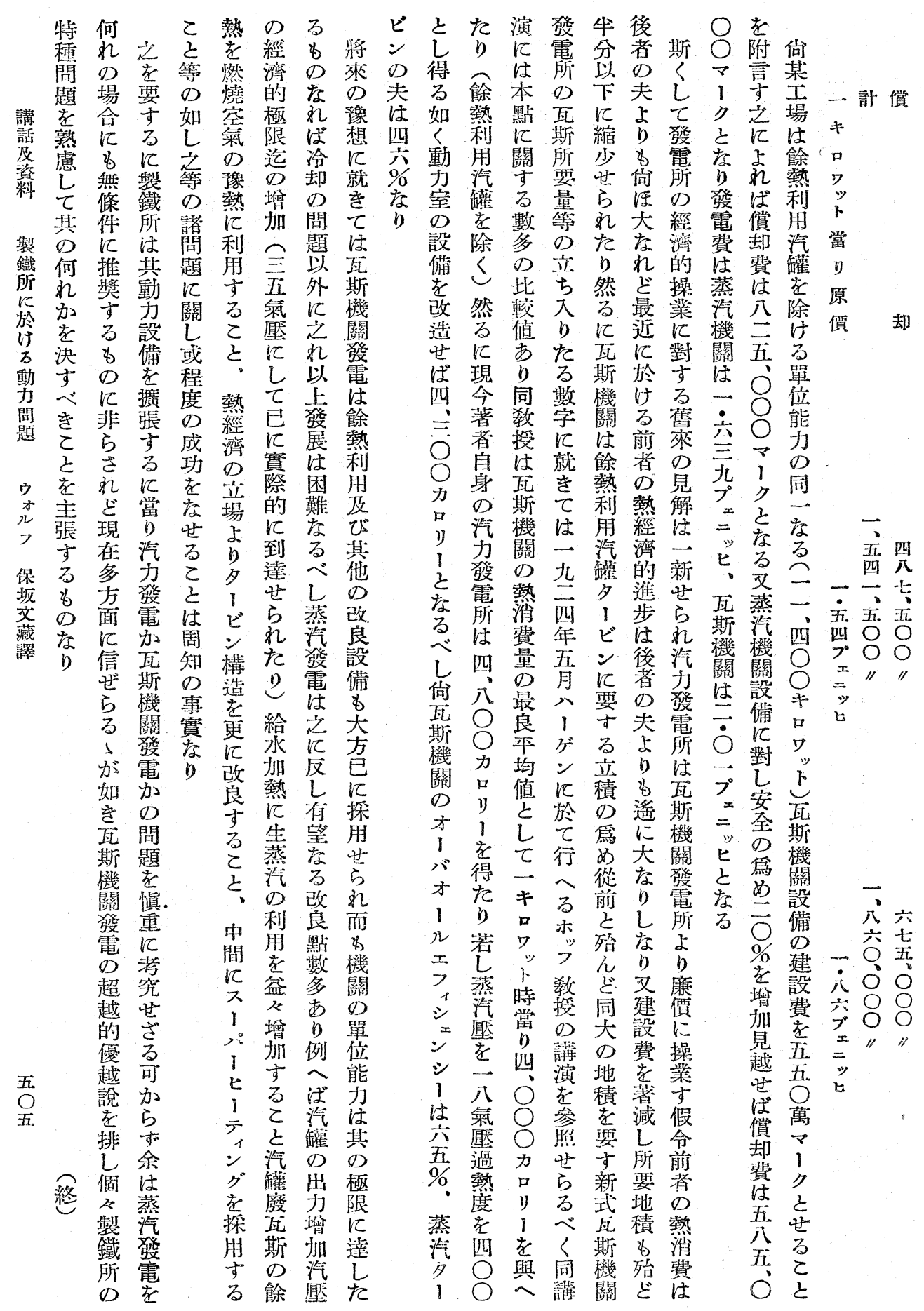

